\title{
大空間エアドームの夏期の熱負荷の推定に関する研究 STUDY ON ESTIMATION OF THERMAL LOAD IN A LARGE SCALE AIR SUPPORTED DOME UNDER SUMMER CONDITIONS
}

\author{
佐野武仁* \\ Takehito SANO
}

\begin{abstract}
In the previous study, the vertical temperature inside a large-scale air-supported dome was calculated, using multipleregression analysis. The result showed that it was accurate. And in this study, the thermal load was calculated with the actual temperature instead of the estimated one, and compared the result with the heat extraction rate by cooling tower. It was conf irmed that the result was accurate. This study indicates that if solar radiation, outdoor air temperature, humidity and wind velocity, meteorological data and the interior heat generation from lights and people are obtained, the vertical temperature distribution and thermal load inside a large-scale air-supported dome can be calculated with accuracy. Results show that about $90 \%$ of the cooling load was concentrated in the living zone within 5 meters of the ground level while the remaining $10 \%$ of the load on the non-air conditioned zone. The thermal absorption and radiation of long wave in air space, from floors, walls, furniture and exhibit, was calculated with Hottel's function. It appears that the air space has some thermal absorption and radiation. It was confirmed that a boundary 5 meters of the ground level was formed, and the thermal load was absorbed in the lower air layer and rejected in the higher.
\end{abstract}

\author{
Keywords : membrane structure, multiple regression analys is, solar radiation \\ vertical temperature distribution, thermal laad \\ 膜構造建築, 重回帰分析, 日射, 垂直温度分布, 熱負荷
}

\section{1. 本研究の目的と既報の研究}

既報の研究 ${ }^{1}$ では、膜材の光特性と熱特性について明 らかにした。また、エアードムの実剆で得られた水平面 全天日射量、外気温度 - 湿度、外風速の 4 気象条件を与 え、線形重回㷌分析の手法を用いて重直温度分布や居住 域の湿度を比較的容易に求める方法 2 ( 2 )を提案した。 これに引き続き本論文では、便宜上室内の空間を居住域 （空調域）とその上部の非空調域とに分け、夏期の居住 域の冷房負荷や上部非空調域の熱負荷の推定を行い、妐 工後の建物の冷房負荷や熱負荷の予測、最適運転制御や 設計時点での冷房負荷を推定する方法について提示する。 なお、室温が設計値に近い值で制御されている居住域の 負荷、すなわち、実際にパッケージにかかる負荷を特に 冷房負荷とし、非空調域の熱流や膜面、床面など各部位 の熱流を熱負荷とする。なお、非空調域の熱負荷とは、 室温は成りゆきで上部空気層への熱の出入りを示すもの で直接パッケージにかかる冷房負荷にはならない。また、
この研究は、宮川保之 ${ }^{(0)}$ 、戸河里敏・早川真・荒井良 延 ${ }^{11) \sim 13)}$ などの既往の大空間の研究と比較して、線形 重回帰分析の手法を用いて実測点の垂直温度分布、湿度 などが判っていること、膜自体には熱容量がほとんど無 いので膜面が吸収する太陽放射の受熱量によって膜内外 の表面温度や垂直方向への温度が瞬時に上下すること、 膜材は熱貫流抵抗が小さいので、膜内外での表面熱伝達 率が熱負荷に影響を与えること、室内の湿度が上昇する と空気中の水蒸気が長波長放射を吸收 ${ }^{14)}$ 乙、室内湿度 の高い日は居住域を冷房すると上下温度分布に差ができ る要因になると考えられること、などが異なる。実測し た温湿度と線形重回帰式を用いて求めた室内温湿度の推 定值は前報 ${ }^{2}$ で提示した通り精度よく合うので、推定值 の代わりに実測値を用いて計算してもその精度は高いと 考えられる。そこで、以下の計算では推定值に替えて実 測值を用いる。つぎに、居住域の冷房負荷と冷却水塔の 除去熱量とを照らしあわせエアドームの熱負荷について

* 昭和女子大学生活科学部生活美学科 教授 · Prof., Showa Women's University, Dr. Eng. 博士 (工学) 
検証する。この計算方法の特徵は、気象条件の 4 パラメ ーターを与え、居住域の冷房負荷や非空調域の熱負荷を 線形重回㷌分析の手法を用い推定することである。

\section{$2 エ ア ト ゙ ー ム の$ 概要}

図 1 に建築・設備の概要、垂直各点の温度、水平面全 天日射量、外気の温度 - 湿度、外風速の実測点を示す。 冷房は直吹き水冷パッケージを設置し、吹出口の中心は 床上 $1.8 \mathrm{~m}$ である。また、図 $1 \mathrm{c}$ ) に加圧送風機の吹 出口断面を示したが、吹出口の中心は床上 $3.9 \mathrm{~m}$ の位 置で在室者に対する新鮮空気の供給とエアリーク補給を 兼ねて承平に吹き出している。吹出し気流は、自由噴流 として取り扱う。エアリークは主に膜材とコンクリート

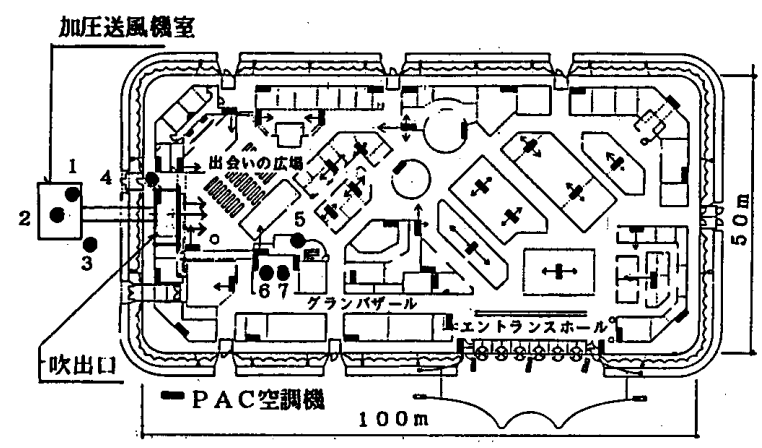

a) Nドーム平面図

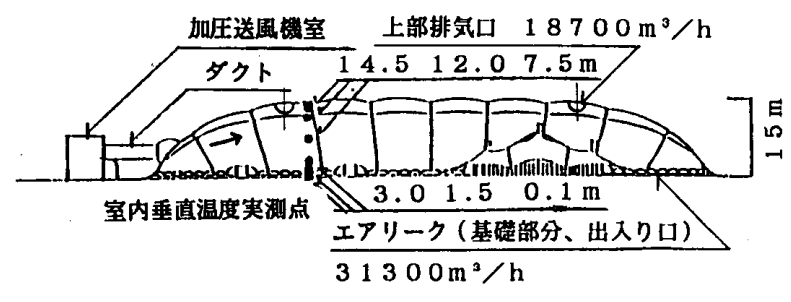

b ) 立面図

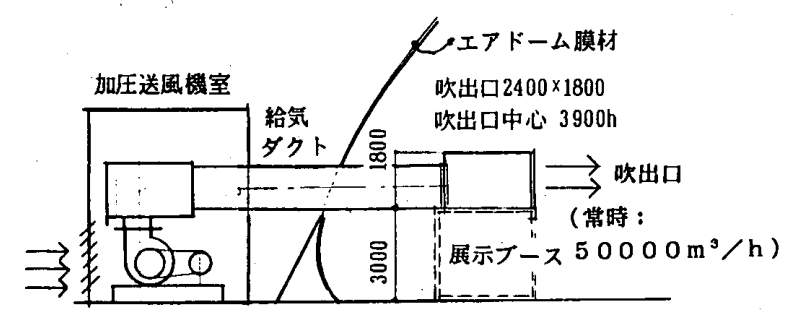

c）加圧送風機の吹出口

\begin{tabular}{|c|c|}
\hline $\begin{array}{l}\text { ·実測点 } 1: \text { 水平面全天谢量 } \\
\text { (計 } 30 \text { 点) } 2: \text { 外気温湿度 }\end{array}$ & $\begin{array}{l}5: \text { 室内垂直温度、膜面温度 (計 } 10 \text { 点) } \\
6 \text { : 室内湿度 (床上 } 1.5 \mathrm{~m})\end{array}$ \\
\hline $\begin{array}{l}3: \text { 屋外地中嗢度 } \\
4: \text { 室内地中温度 }\end{array}$ & $7:$ 透過日射量 \\
\hline 空間容積 $: 51000 \mathrm{~m}^{3}$ & - 加圧送風機：50000 $\mathrm{m}^{3} / \mathrm{h}, 3$ 台 \\
\hline ·居住域容樌 : $14800 \mathrm{~m}^{3}$ & 平常時 1 台： $50000 \mathrm{~m}^{3} / \mathrm{h}$ \\
\hline - 膜表面皘 : $6120 \mathrm{~m}^{2}$ & 非常時3台: $144000 \mathrm{~m}^{3} / \mathrm{h}$ \\
\hline : $\quad 4295 \mathrm{~m}^{2}$ & - 常時換気回数 : $\quad 0.98$ 回 $/ h$ \\
\hline 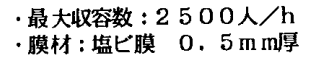 & $\begin{array}{cl}\text { - 給気口 } & : 2400 \times 1800 \\
\text { 給気量 } & : 50000 \mathrm{~m}^{3} / \mathrm{h}\end{array}$ \\
\hline $\begin{array}{r}\text { ·冷屏設備：水冷バッケージ } \\
\text { Comp 7． } 5 \mathrm{~kW} \times 5 \text { 1台 } \\
\text { ・下咅 }\end{array}$ & $\begin{array}{c}\cdot \text { 上部排気口 : }: 790 \phi \times 2 \\
\text { 上部排気星 : } 18700 \mathrm{~m}^{3} / \mathrm{h} \\
\text { 洵量、エアリーク量 : } 31300 \mathrm{~m}^{3} / \mathrm{h}\end{array}$ \\
\hline
\end{tabular}

図1 Nドーム建築設備概要および実測点

\section{口記号説明}

1) 柴页磁糸

Qad、Q au :居住域、非空調域の空気の保有熱量 [ $\mathrm{kW}]$

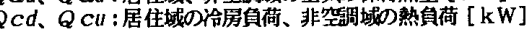

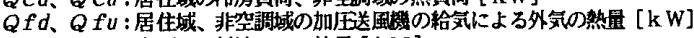
$\mathrm{Qg}$ : 床面での対流による熱量 [ $\mathrm{kW}]$

$Q h:$ 人体の発然量 $[\mathrm{kW}]$

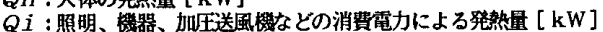

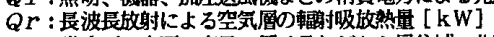

$Q r d 、 Q r u$ : 膜表面、林面、家具・展示品などから居住城、非空調域の空気層

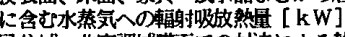

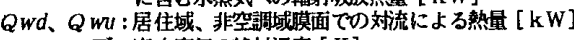
$T^{*}$ : 室内些気 0 䊉対温度 [ K]

$T g 、 T g^{*}:$ 外表面晹度 $\left[{ }^{\circ} \mathrm{C}\right]$ 、同絶対温度 $[\mathrm{K}]$

$T e g$ : 透過日射量、室内空気温度を考虜した林表面の等価温度 $\left[{ }^{\circ} \mathrm{C}\right]$ $T \boldsymbol{g} r:$ 地中温度 $\left[{ }^{\circ} \mathrm{C}\right]$

$T i u, T$ i $u^{*}:$ 上部空気の平均温度 $\left[{ }^{\circ} \mathrm{C}\right]$, 同空気の桷対温度 $[\mathrm{K}]$

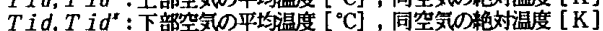

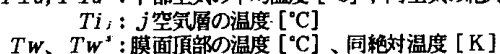

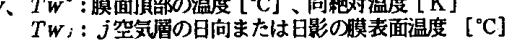

$A_{i}, A: j$ 空気層の日向または竞の膜表面糟、ドーム全膜表面積 $\left[\mathrm{m}^{2}\right]$ $A g:$ 床面積 $\left[\mathrm{m}^{2}\right]$

aw, $\boldsymbol{a}_{a}:$ 膜面、楂面の白射吸収事 $[-]$

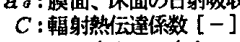

$c:$ 円の中心から床までの高さ $[\mathrm{m}]$

$c q:$ 惢答保数の共通比 $[-]$

$C p$ : 空気の定圧比缹 [W/ $/ \mathrm{kg} \cdot \mathrm{K}]$

$d:$ 脱材の厚さ $[\mathrm{m}]$

$E \cdot I:$ 電压 $[V]$. 電流 $[A]$

$H i$ : 床面から测定点までの高さ $[\mathrm{m}]$

Ho、Hdex : 外気およひ居住域ての排艾の此エンタルビ $[\mathrm{J} / \mathrm{kg}]$

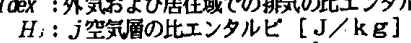

$I:$ 水平面全天谢量 $\left[\mathrm{W} / \mathrm{m}^{2}\right]$

$I_{0}:$ 太隔放射 $\left[\mathrm{W} / \mathrm{m}^{2}\right]$

$I_{D N}, I_{S M}$ : 法線面直違日射量、天空日射量 $\left[\mathrm{W} / \mathrm{m}^{2}\right]$

$K:$ 就買清茾 $\left[\mathrm{W} / \mathrm{m}^{2}: \mathrm{K}\right]$

$K k:$ 水平面直違日射量と水平面全天时量の比 $[-]$

$P$ : 大気透過率 $[-]$

$R: x>N-\Delta \sigma$ 半怪 $[\mathrm{m}]$
$V:$ 風速 $[\mathrm{m} / \mathrm{s}]$

$V d, V u$ :居住域、非空䚴城の排気風量 $\left[\mathrm{m}^{3} / \mathrm{h}\right]$

$V_{0}:$ 加压送風風量 $\left[\mathrm{m}^{3} / \mathrm{h}\right]$

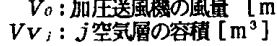

$X M, 、 Y M,:$ 床 $\sigma$ 吸然応答、貫流店答 $\left[\mathrm{W} / \mathrm{m}^{2}\right]$

YAKAN : 夜間放射 $\left[\mathrm{W} / \mathrm{m}^{2}\right]$

$N h$ : 在室者数 [人]

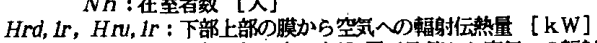

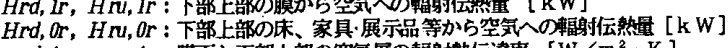

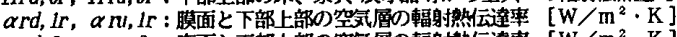

$\alpha r d, 0 \mathrm{r}, \alpha \pi u, 0 r$ : 休面と下部上部の空気層の輻射努伝逢率 $\left[\mathrm{W} / \mathrm{m}^{2} \cdot \mathrm{K}\right]$

$\alpha i 、 \alpha o:$ 膜内表面、外表面䌊合熱云達率 $\left[\mathrm{W} / \mathrm{m}^{2} \cdot \mathrm{K}\right]$

$\alpha i c, \alpha \propto c$ : 膜内表面、外表面対流然云達 $\left[\mathrm{W} / \mathrm{m}^{2} \cdot \mathrm{K}\right]$

$\alpha_{0}:$ 床面 0 秎合然伝道率 $\left[\mathrm{W} / \mathrm{m}^{2} \cdot \mathrm{K}\right]$

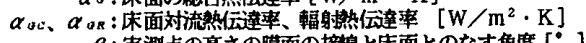
$\beta:$ 実測点の育さの膜面の接楾 $\gamma:$ 空気の比重量 $\left[\mathrm{kg} / \mathrm{m}^{3}\right]$

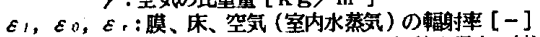

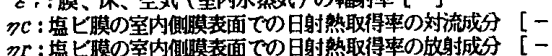
$\eta r:$ 坆七膜 $の$ 室内唄膜表面で日 $\eta t:$ 坆ビ膜の日射然取得率

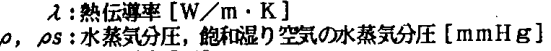
$\phi:$ 相対湿度 [\%]

$\cos \phi:$ 方慗 $[-]$

$\sigma:$ :ュュファン・ポルツマン常数 $\left[5.67 \times 10^{-8} \mathrm{~W} / \mathrm{m}^{2} \cdot \mathrm{K}\right]$

$\mathrm{Cb}:$ 黒体の輻嫦数 $5.67\left[\mathrm{~W} / \mathrm{m}^{2} \cdot \mathrm{K}\right]$

$f:$ 水蒸気分圧 $\rho$ と空氞層の有效㫗さ $L a$ の積 $[-]$

$\mathrm{La}:$ 空氞屏の有効県さ $[\mathrm{m}]$

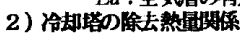

Qcm : コンプレッサーの等負荷 [ $\mathrm{kW}]$

$Q C p$ : 洽却水ボンプの繁負荷 $[\mathrm{kW}]$

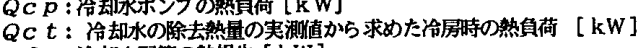
$Q P:$ 冷却水配管の然提失 [ $\mathrm{kW}]$

$C p:$ 水の比热 $[\mathrm{W} / \mathrm{kg} \cdot \mathrm{K}]$

$K p$ : 配管内径と外佳との間の然蛽流率 $\left[\mathrm{W} / \mathrm{m}^{2} \cdot \mathrm{K}\right]$

$L$ : 冷却水量 $\left[\mathrm{m}^{3} / \mathrm{h}\right]$

$T p 、 T g i$ : 管内表面温度、地中温度 $\left[{ }^{\circ} \mathrm{C}\right]$

$\operatorname{Tr} T s$ : 冷却塔 0 冷却水の入口・出口温度 $\left[{ }^{\circ} \mathrm{C}\right]$

$d_{1}, d_{2}$ : 配管の内径および外径 $[\mathrm{m}]$

$l:$ 各口侱の配笛辰 $[\mathrm{m}]$

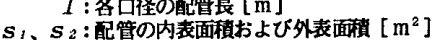

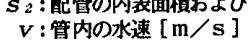

$\alpha_{1}, \alpha_{2}:$ 水俳の表面整伝達草 $\left[\mathrm{W} / \mathrm{m}^{2} \cdot \mathrm{K}\right]$

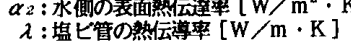

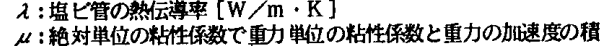

$\mu:$ 絶対単位 $\sigma$ 粘性係数

3) その他

$\nu:$ 動粘性係数 $\left[\mathrm{m}^{2} / \mathrm{s}\right]$

$X$ : 床面と真部

$Y:$ 全伶房算荷 $[\mathrm{kW}]$

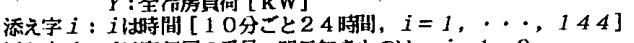

添え字 $j: j$ は究気層の番号。明示無きものは、 $j=1,2, \cdots \cdots, 6$ $J=1,2 ， \cdots, N J$ を示し、NJは応答保数の打切り項数を示す。 
基礎との接続面が多く、出入口、非常口、物品搬入口の 隙間や内圧調整のために設けた頂部排気口へと流れる。 給排気量、エアリーク量などは図 1 の下段に示した。

2. 1 自然室温と冷房時の室温

図 2 は、夏期ドーム内の床上 $3 \mathrm{~m}$ の垂直温度の実测值 と線形重回帰式で求めた自然室温との関係を示したが、 この温度差は居住域を冷房することによって生じるもの で、加圧送風機の吹き出し気流による居住域の冷房空気 の誘引、上部の非空調域に設けられた排気口への熱流な

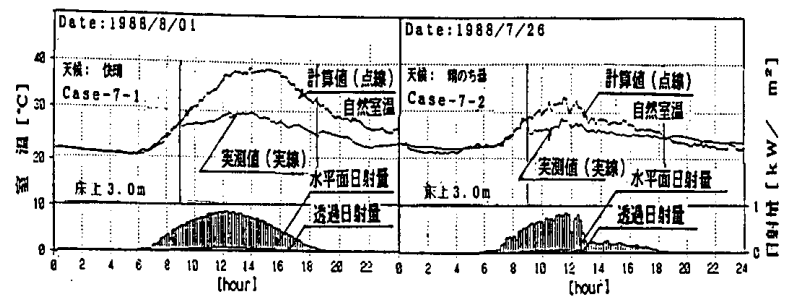
a) $8 / 1:$ 快晴
b ) $7 / 26:$ 晴後畩

図 2 床上 $3 \mathrm{~m}$ の自然室温と冷房時の室温の実測值 ${ }^{21}$

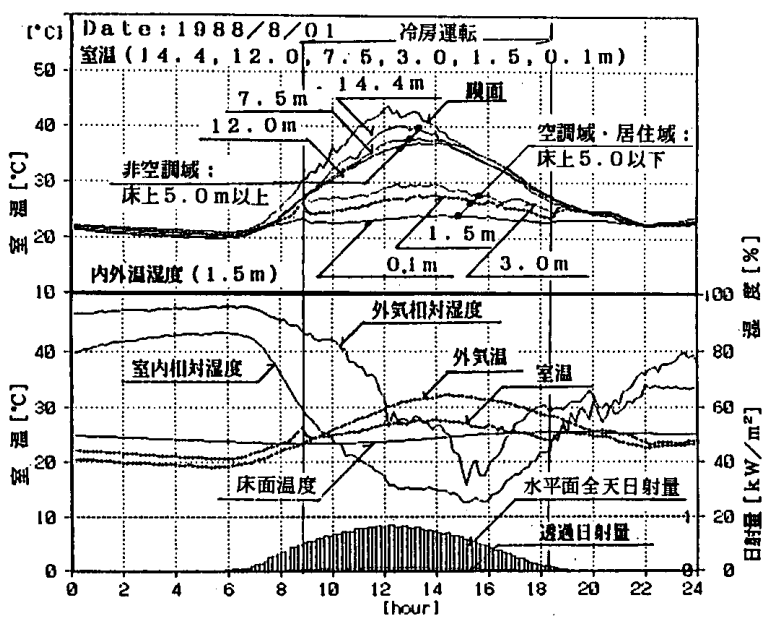

どが考えられる。居住域をパッケージで冷房するとその 影響は頂部にまで及ぶことが前報 ${ }^{2}$ で明らかになってい る。

\section{2 居住域と非空部域の設定}

図3に8月 1 日の気象条件と垂直温度分布の実測值を 示す。空調運転時は床上 $3 \mathrm{~m}$ と $7.5 \mathrm{~m}$ の実測点で最大 $8{ }^{\circ} \mathrm{C}$ 程度の温度差があるが、居住域の床上 $0.1 \mathrm{~m}$ の点 は $24^{\circ} \mathrm{C}$ 前後、床上 $1.5 \mathrm{~m}$ は設計值の $26^{\circ} \mathrm{C}$ 前後、休 上 $3 \mathrm{~m}$ の点は $29^{\circ} \mathrm{C}$ 前後を示している。热真荷計算に当 たって垂直方向への温度差が大きい床上 $5 \mathrm{~m}$ の点でドー 厶内を上下に分け、便宜上下部を居住域（空調域）、上 部を非空調域として取り扱う。

\section{3. 大空間エアドームの夏期の熱角荷の推定}

図 4 に示す太陽放射 (1)のうち膜面を透過する日射熱取 得率 $n t^{1 /}$ は、

$$
\eta t=n+n c
$$

となる。膜面を透過した短波長放射と膜面に吸収された 太陽放射のうち長波長放射を含めて、室内側に再放出さ れる輻射成分 $\eta r$ は(2)となり、室内空気 (3)を通って直接 床面などに到達する熱流である。この熱流 $\eta r$ は、受熱 面で一部は(4)として反射するが、このうち大半は床面、 瞙面、家具・展示品などの表面で吸収する。吸収された 熱の大半は瞬時に対流成分(5)として室内への熱負荷とな る。これと同時に、床面などで熱容量のある部位に吸収 された熱の一部は地中などへの熱流となるがタイムラグ を持って再び対流成分(5)として室内への熱負荷となる。 これらの過程を経て膜面を透過した輻射熱は室内の熱負 荷になるが、輻射熱のうち長波長放射の一部は空気中の

図3 夏期の日射量、温湿度などの実測値と 居住域と非空調域の境界（ $8 / 1$ : 快晴 $)$

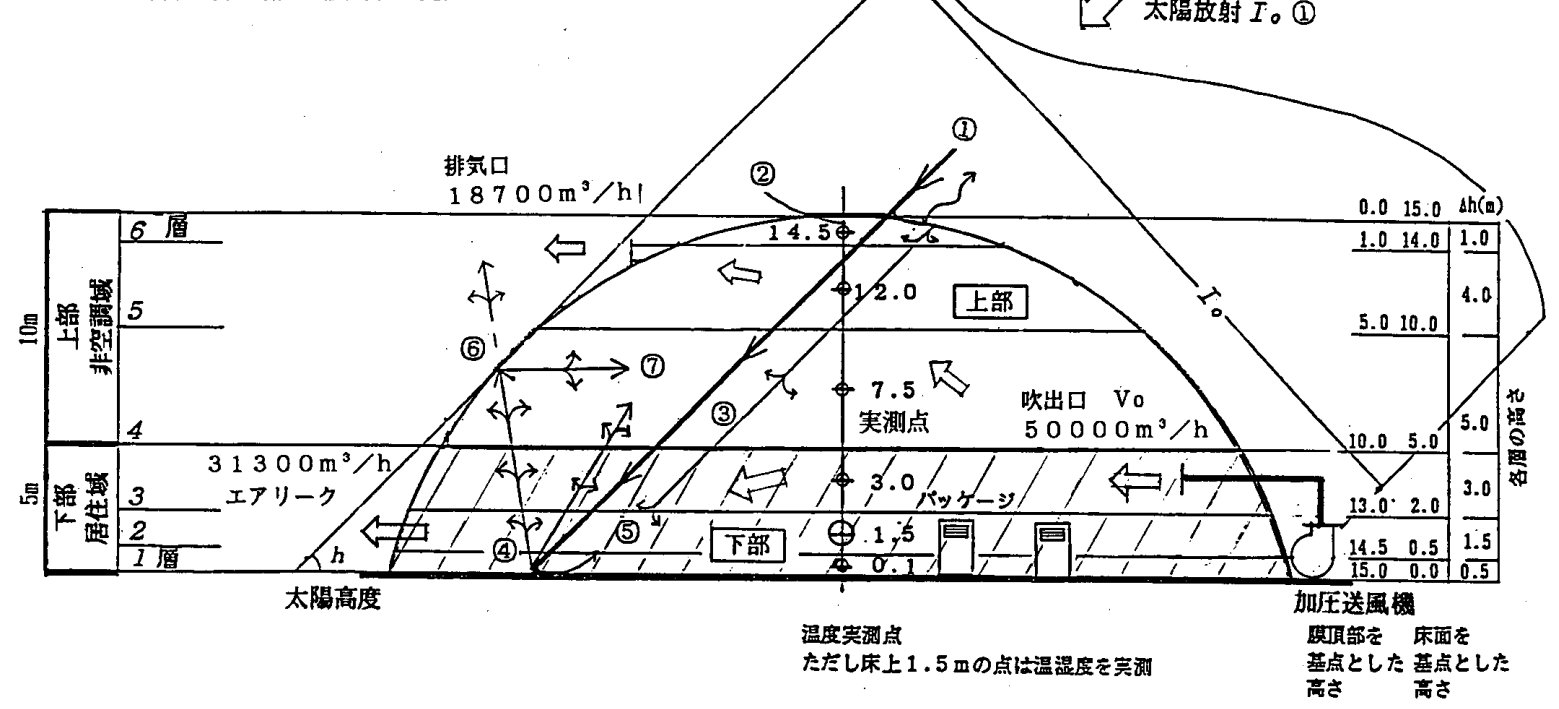

図4エアドームの熱計算モデルの概要 
水蒸気(3)や(7)に吸収される。この吸収分を除いた熱流に よって各面の熱平衡は成り立つ。輻射熱は各部位での熱 平衡には関係するが、居住域の冾房負荷や非空調域の熱 負荷に直接関係することはなく、各面で吸収されたのち 対流成分として室内の熱負荷となる。つきに、式（1） に示した対流成分 $\eta c$ は、膜内表面で室内側の空気に放 出され熱負荷となる。ここでは既報 " で示した通り $\eta r$ は $13 ， 0 \% 、 \eta c$ は、 $3 ， 4 \%$ 、日射熱取得率 $\eta t$ は これらを合計した 16 ．4\%となり、残りの83．6\% は膜外表面で大気への放熱として計算する。ここで、床 面の吸収率を $\eta r$ の．75 とすると、残りの0．25、 すなわち、 $n r$ のうち透過率 $13 \%$ と反射率 $25 \%$ の積 の3. $25 \%$ は、多重反射を繰り返し膜面を透過し大気 中へ放熟するかまたは膜面に吸収され室内外の総合熱伝 達率の比とその温度差の積に配分され室内外への熱流と なる。また、居住域の冷房負荷や非居住域の熱負荷を計 算するに当たって、膜材や床面の内表面熱伝達率の対流 成分が判れほ冷房負荷や熱負荷の推定は可能であり、瞙 面、床面などで再反射した輻射熱は直接パッケージの負 荷にはならないと考える。つぎに、前報 ${ }^{2}$ で示した通り 晴天日の線形重回帰式を用いて天候の異なる别の日の垂 直温度分布や室内の湿度を推定しても推定檤と実測值は 精度よく合うので、垂直温度分布の推定值に替え本稿で は実測值を用いて冷房負荷や熱負荷の推定を行う。

\section{1 熱負䓟の内訳}

1) 大空間エアドームの夏期の熱平衡

エアドームの居住域の冷房負荷および上部非空調域の 鶖負荷を求める。計算に当たって図 4 に示した通り垂直 温度分布の実測点を中心に、上下 6 層 $(j=1,2 ， \cdots$

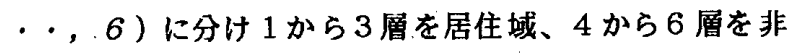

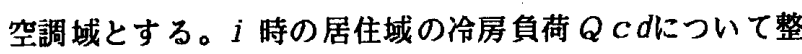
理すると、

$$
\begin{aligned}
Q c d(i)= & \{Q w d(i)+Q w u(i)\}+Q g(i)+Q a d(i)+Q r d(i)+Q f d(i) \\
& +Q i(i)+Q h(i)
\end{aligned}
$$

となる。同様に非空調域の熱負荷 $Q c u$ は、

$$
Q c u(i)=\{Q w(i)+Q w d(i)\}+Q a u(i)+Q r u(i)+Q f u(i)
$$

となる。式（2）の冷房負荷 $Q c d$ は、瞙面からの対流 熱量 $Q w U+Q w d$ 、床面からの対流熱量 $Q g$ 、居住域の 空気の保有熱量 $Q$ ad 、膜表面、林面、家具・展示品な どから居住域の空気層に含む水蒸気への吸故熱量 $Q r d$ 、 加圧送風機の給気による外気の熱量 $Q f d$ ：照明・機器 ・加圧送風機などの消費電力による発熱量 $Q i$ 、人体の 発熱量 $Q h$ の和となる。 $Q W d 、 Q W u$ は、 $j$ 空気層の温 度 $T i_{i}$ (i)と同じ高さの膜面温度 $T W$; (i)を比較し $T i$; (i) $<T W i(i)$ のときは上部非空調域への熱流とし、こ の逆は下部居住域への熱流とする。また、式（3）は上
部非架調域の熱負荷について示したが、下部居住域と同 様に各項の熱流の和として表すことができる。

\section{2）膜内表面の熱伝達率}

膜材の熱負荷は、膜内表面熱伝達率が関係するので頂 部で実測した值を拡張して用いる。頂部膜面の温度 $T w$ および膜面に最も近い垂直温度 $T i$ 。の実測值を用い、室 内側の膜表面対流熱伝達率 $\alpha i c$ を知数として収束計算 を行う。図 5 に示した通りこの結果を用いて垂直温度 $T$ $i$; と同じ高さの膜面温度 $T W$; を求め膜面での熱負荷を 計算する。

\section{（1）実澌值を用いて求めた頂部膜内表面の対流熱伝達 率および膜面温度}

膜面を通して室内へ出入りする熱流の計算では、膜内 表面対流熱伝達率が必要となる。そこで、頂部 $T W の$ 実 測点で熱平衡をたて内表面熱伝達率を末知数として収束 計算を行い実測值の膜面温度と熟平衡式で計算した計算 值の表面温度が許容值以下になるまで計算し、このとき の内表面熱伝達率を求める。ただし、膜材の熱容量は無 視できるとする。膜面の吸収率を $a$ w、外部から膜外表 面が受ける熱流を $q W_{n}$ ，外表面から室温へ向かう熱流を $q W_{2}$ とすると $q W_{j}=q W_{2}$ となる。室内外の総合熱伝 達率を $\alpha$ i、 $\alpha$ oとすると、

$$
\begin{aligned}
& \text { aw }\{I(i)-Y K W\}+\alpha o(i)\{T(i)-T w(i)\} \\
& =1 /\{d / \lambda+1 / \alpha i(i)\} \cdot\left\{T w(i)-T i_{b}(i)\right\}
\end{aligned}
$$

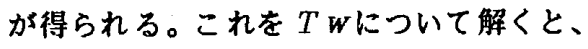

$$
\begin{aligned}
T w(i) & =K(i)[\{1 / \alpha i(i)+\alpha / \lambda\}\{T a(i) \\
& \left.+a w(I(i)-Y A K W) / \alpha \alpha(i)\}+T i_{s}(i) / \alpha \alpha(i)\right]
\end{aligned}
$$

が求められる。ここで、Kは熱貫流率を示し、

$$
K(i)=1 /\{1 / \alpha \sigma(i)+d / \lambda+1 / \alpha i(i)\}
$$

となる。ドーム内の空間は膜および床面で覆われた空間 であるので膜面の単位面樍から床面などの他の全ての部 位との輻射交換熱量があるとし、膜面と他の部位との形

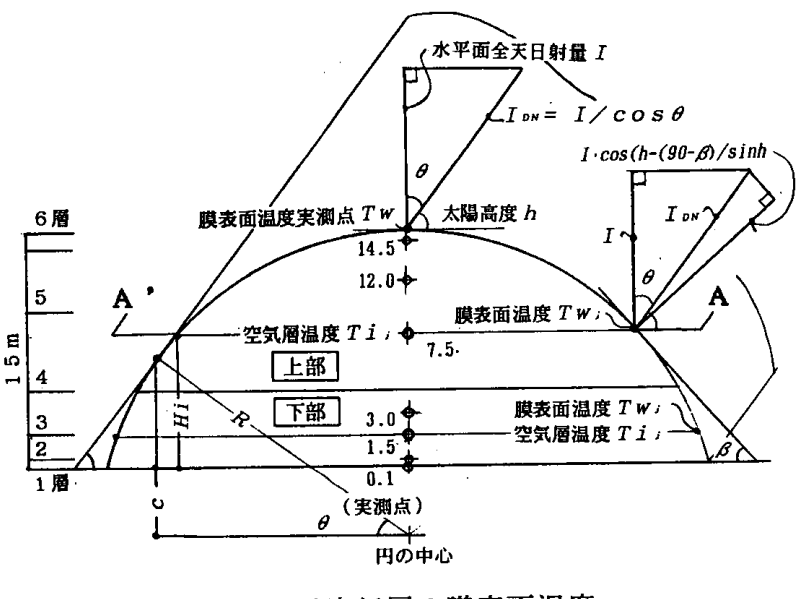

図5 j空気層の膜表面温度 
態係数を 1 とすると室内側表面熱伝達率の輻射成分 $\alpha i r$ 15)は、

$$
\operatorname{\alpha ir}(i) \doteqdot \varepsilon^{\prime}, \varepsilon_{r} \sigma\left\{T W^{*}(i)^{4}-T g^{*}(i)^{4}\right\} /\left\{T W^{*}(i)-T g^{*}(i)\right\}
$$

となる。また、膜面の外表面対流熱伝達率 $\alpha$ ocは膜材表 面を普通の面と考えJ u r g e s の実駼式を用いる。内 表面対流熱伝達率 $\alpha i c^{15)}$ はニュートンの冷却則の自然 対流の式を用いると、

$$
\begin{aligned}
& \alpha 0 x(i)=5.0+3.4 V(i) \quad V(i) \leqq 5 m / s \\
& \alpha 0 \alpha(i)=6.14 V(i)^{a .78} \quad V(i)>5 m / s \\
& \alpha i c(i)=2.3\{T w(i)-T i(i)\}^{a 25}
\end{aligned}
$$

と表せる。実測値を用いて計算すると、図 6 に示した通 り頂部膜面の熱伝達率 $\alpha i r 、 \alpha i c$ はいずれも 5 から 5 . $7 \mathrm{~W} / \mathrm{m}^{2} \cdot \mathrm{K}$ 、内表面総合熱伝達率は 10 から 11 ，4 $\mathrm{W} / \mathrm{m}^{2} \cdot \mathrm{K}$ の範囲を変化する。熱負荷計算では図 6 に示 した值を用いる。ただし、外気㑡の熱伝達率は風速の影 響を受け変化するが室内側はほぼ一定と兒なしてよい。

\section{（2）垂直温度分布の実湘点と同じ高さの膜面温度と熱} 角荷

図 5 に示した通り実测点 $T i$; から水平線を引き、こ の線が膜表面と交わる点の接線と床表面のなす角度を $\beta$ とする。i 時の日向の膜面温度は式 (5) の $\mathbf{a}_{\text {w }} \cdot I$ (i) を $a_{w} \cdot I(i) \cdot \cos (h-(90-\beta)) / \sin h$ （i）に置き替え整理すると、

$$
\begin{aligned}
T W_{j}(i)= & K(i)[\{1 / \alpha i(i)+\alpha / \lambda\}\{T a(i) \\
& +\operatorname{taw}(I(i) \cdot \cos (h-(90-\beta)) / \sinh (i)-Y K W N) \\
& \left./ \operatorname{\alpha o}(i)\}+T i_{j}(i) / \operatorname{aod}(i)\right]
\end{aligned}
$$

となる。また、膜面の日影部分は天空日射量のみについ て計算するのでブーカのの式とベルラーゲの式から直散分 離を行って求めた水平面全天日射量に対する水平面直達 日射量の割合とし $i$ 時の值を $K k(i)$ とすると、

$$
\begin{aligned}
& K k(i)=I_{\text {DN }}(i) \cdot \sin h(i) / T(i)=P^{1 / \sinh (i)} /\left\{P^{1 / 4 \sinh (i)}\right. \\
& \left.+\left(1-P^{1 / \sinh (i)}\right) / 2(1-1.4 \ln P)\right\}
\end{aligned}
$$

となり、単位面積当たり $\{1-K k(i)\} \cdot I(i)$ の熱流 がある。日影の膜の膜面温度は式（10）の $a_{*} \cdot I(i)$ の部分が $a_{\#}\{1-K k(i)\} \cdot I(i) \cdot \cos (h-(9$ $o-\beta)) / \sinh (i)$ に置き替わるので、

$$
\begin{aligned}
T W_{j}(i)= & K(i)\left[\{ 1 / \alpha i ( i ) + d / \lambda \} \left\{T a(i)+a_{w}(1-K k(i))\right.\right. \\
& \cdot I(i) \cdot \cos (h-(90-\beta)) / \sinh (i)-Y A K W) \\
& \left./ \operatorname{ao}(i)\}+T_{\sigma}(i) / \operatorname{aoc}(i)\right]
\end{aligned}
$$

となる。日向と日影の判別は、円の中心から床までの高 さを $c$ 、床面から測定点の高さを $H i$ とすると、

$$
H i \geqq R \cdot \cosh (i)-c
$$

$$
H i<R \cdot \cosh (i)-c
$$

となり図 5 に示す $\mathrm{A}$ 点、 $\mathrm{A}$ '点の膜面の日向、日影を判 別する。また、下部膜面での対流による熱量 $Q w d d 、$

$$
Q w d(i)=\sum_{i=1}^{3} \alpha i c\left\{T W_{i}(i)-T i(i)\right\} A
$$

となり $\mathrm{A}$ 点、 $\mathrm{A}^{\prime}$ 点は別々に計算する。また、上部膜面 のQWUも同様に計算する。ただし、膜面での対流熱量 に関して、j空気層の温度 $T i$; (i)と膜面温度 $T W ;(i)$ を 比較し、T $i_{i}(i)<T W_{i}$ (i)のときは非空調域への熱流と し、この逆の場合は居住域への熱流とする。夜間放射に ついては夏期の標準気象データでは 24 から $26 \mathrm{~W} / \mathrm{m}$

2 の範囲を変化するか、ここでは $25 \mathrm{~W} / \mathrm{m}^{2}$ とした。

\section{3 ) 床面の対流熱伝達率と熱負荷}

図 7 に示したようにレスポンスファクター16) 法を用 い床表面で熱平衡式をたてる。 $i$ 時の床面の温度を $T \boldsymbol{g}$ 、 透過日射量、室内空気温度を考慮した床表面の等価温度 を $T$ e g、床面の総合熱伝達率を $\alpha$ 。すすると、

$$
T e g(i)=a_{i s} \cdot\left\{I(i)-Y K W W / \alpha_{\theta}(i)+T i_{1}(i)\right.
$$

となる。床面が受ける全熱流 $q g$ はは、

$$
q g_{i}(i)=\alpha_{s}(i)\{T e g(i)-T g(i)\} A g
$$

となる。ただし、 $a_{\text {\& }}=0.75$ とし、ク瑐報”で示 した $0 １ 3$ を用いる。つぎに、 $i$ 時に 1 側の床表面か ら0 側の地中へ向かう熱流を計算する。0側の地中の温 度 T g r は2 4 時間一定とする。熱流計算上は、室温一 定の条件加 0 側の地中の温度が $0{ }^{\circ} \mathrm{C} て ゙$ 床表面温度が $T$ $g-T g r$ の変動があるとしても計算結果は同じである ので地中への熱流 $q g$ 怆、

$$
\begin{aligned}
& q g_{2}(i)=\left\{\sum_{t=0}^{N / l} X M_{i} T g_{(i)-t}-\sum_{t=0}^{N / l} Y_{i} T g r+c q_{(i)-1}\right\} A g \\
& =\left\{\sum_{r=0}^{N . t} X M_{r}\left(T g_{(i)-s}-T g r\right)+C q_{(i)-1}\right\} A g
\end{aligned}
$$

として表せる。ここで $q g_{I}=q g_{2}$ となり床表面での熱 平衡は、

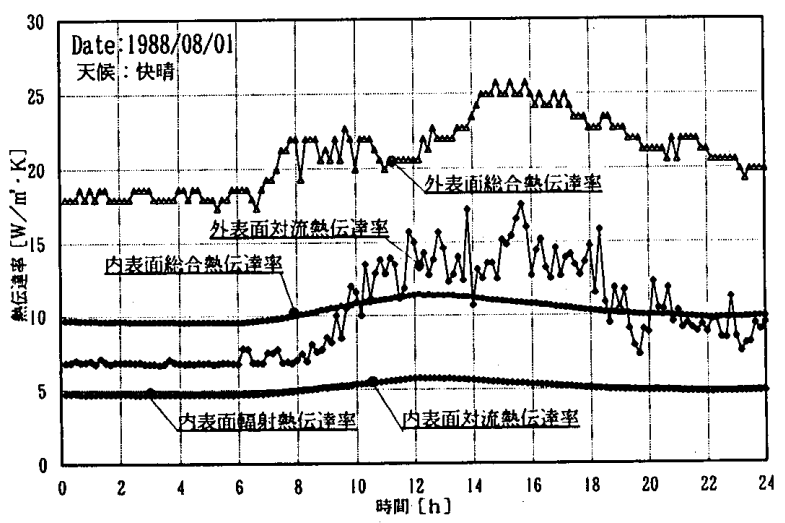

図6 膜内外表面総合熱伝達率および対流熱伝達率 


$$
\begin{aligned}
\alpha_{i}(i) & \{\operatorname{Teg}(i)-T g(i)\} \\
& =\sum_{t=0}^{N J} X M_{i}\left(T g_{(i)-t}-T g r r\right)+c q_{(i) \cdots+I}
\end{aligned}
$$

が成り立つ。式（1８）では、 $T \boldsymbol{g}(i)$ が両辺にあり計

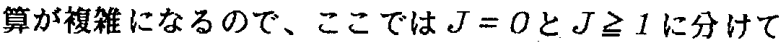
計算する。下式（１９）の右辺の第 1 項は、 $J=0 て ゙ q$

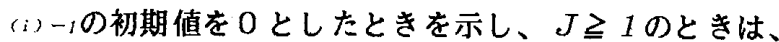
第 2 項について計算し、その結果に第 3 項の $\subset$ q(i)を加えたものが $i$ 時の左辺と等しくなる。T $g(i) に つ$ いて解くと、

$$
\begin{aligned}
& \alpha_{\sigma}(i)\{\operatorname{Teg}(i)-\operatorname{Tg}(i)\}=X M_{0}(T g(i)-T g r) \\
& +\sum_{j=1}^{N /} X M_{i}\left(T g_{(i)-s}-T g r\right)+c q_{(i)-1} \\
& \operatorname{Tg}(i)=\left\{\alpha_{\theta}(i) T \boldsymbol{g e}(i)+X M \operatorname{Tg} r-\sum_{i=1}^{N /} X M_{i}\left(T^{\prime} \boldsymbol{g}^{(i)-, t}-T \boldsymbol{g} r\right)\right. \\
& \left.-c q_{(i)-1}\right\} /\left(\alpha_{a}+X M_{0}\right)
\end{aligned}
$$

として収束計算を行い床表面の温度が計算できる。ここ で、NJは応答係数の打ち切り項数を示す。1 側、0 側 における熱流の計算は周期定常とし、初期值の影響がな くなるまで式（１７）の計算を数日間繰り返し、i時に おける熱取得の前日の值 $q g_{2}(i) *$ と当日の $q g_{2}(i)$ とを 比較し、

$$
\operatorname{lqg}_{2}(i)-q g_{2}(i)^{*} \mid \leqq e
$$

のとき収束したと判定する。図 8 に示した通り $\alpha_{G}$ も同 時に求まる。このうち $\alpha$ 蚹式（7）と同様に、 $\varepsilon 、 の$ 代わりにを。を用いて求めほぼ $4.6 \mathrm{~W} / \mathrm{m}^{2}$ で安定した 值を示した。空調時の対流成分 $\alpha$ 心 は 6 から $6.8 \mathrm{~W} /$ $\mathrm{m}^{2}$ の範团を変化した。しかし、0時から 8 時、14 時か ら24時にかけて $\alpha$ 心は空調時と違った変化をするが、 透過日射量および地表面と室温との温度差による影響に より表面熱伝達率は変化することが判った。つぎに、式 (1 16 ) または式（17) を用いて求めた床面での居住 域への対流による単位当たりの熱負荷を図 9 に示す。床 面から室内に対流成分として放出される熱量は 12 時前 後に最大 $35 \mathrm{~W} / \mathrm{m}^{2}$ となり居住域の熱負荷となる。

4) 上部、下部空気層の保有熱量 単位時間当たりに变化する下部空気層の保有熱量の增加 分 $Q$ a d 、

$$
\operatorname{Qad}(i)=C p \cdot \gamma \sum_{i=1}^{3} V_{V_{i}}\left\{H_{i}(i)-H_{i}(i-1)\right\} d T(i) / d(i)
$$

となる。上部空気層の $Q$ a uについても同様に取り扱う。 室内では人体の発生潜熱などがあるが、居住域で床上 1 . $5 \mathrm{~m}$ の代表点の相対湿度を採用し、 $i$ 時の室内空気の絶 対湿度は一定として計算する。

\section{5 ) 空気中の水蒸気、膜面、林面の輻射吸放熱量}

室内空気では、床面や膜面、家具 - 展示品などとの長
波長放射による熱授受がある。エアドームの長波長放射 による空気層の輻射吸放熱量 Q r は、H o t t e $1{ }^{17}$ のガス体輻射に関する研究を建築に応用した木村の水蒸 気輻射率の計算図表 ${ }^{14)}$ をもとに求めた。木村の式は 2 0から $30{ }^{\circ} \mathrm{C}$ 程度に使用が可能であるのが、ここでは非 空調域の温度が 20 から $50{ }^{\circ} \mathrm{C}$ 程度まで上昇するので式 （３２）を用いて補正し、膜面から床表面と膜面から空 気層への輻射伝熱量、床表面から空気層への輻射伝熱量 を計算する。これらの計算では、空気の温度、膜面温度、 床面温度等が必要になるが下記の手法を用いて計算した。

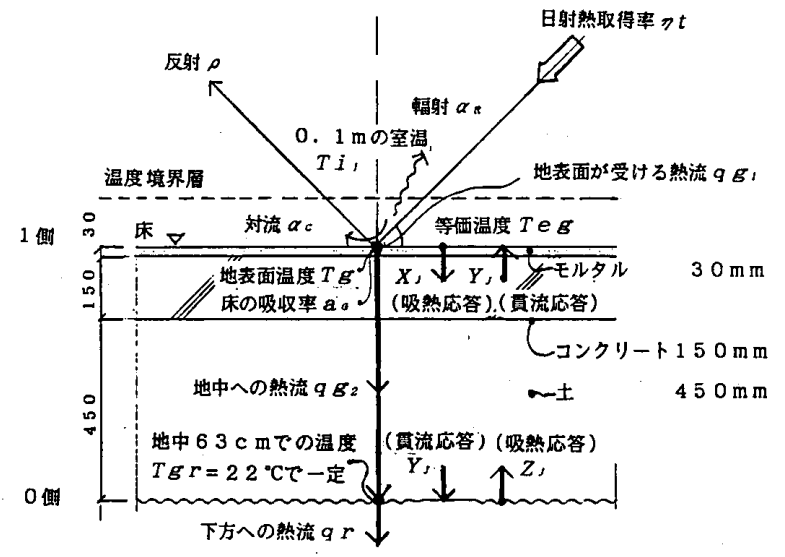

図7レスポンスファクターを用いた床面の熱平衡

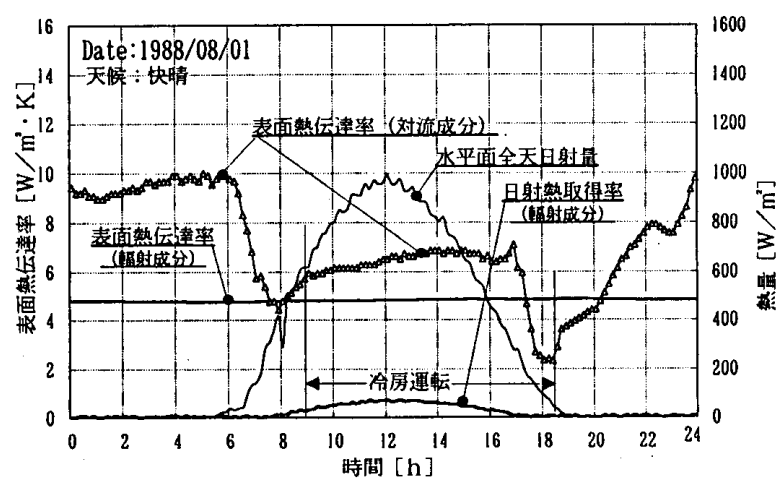

図 8 床内表面の表面熱伝達率（対流成分、輻射成分）

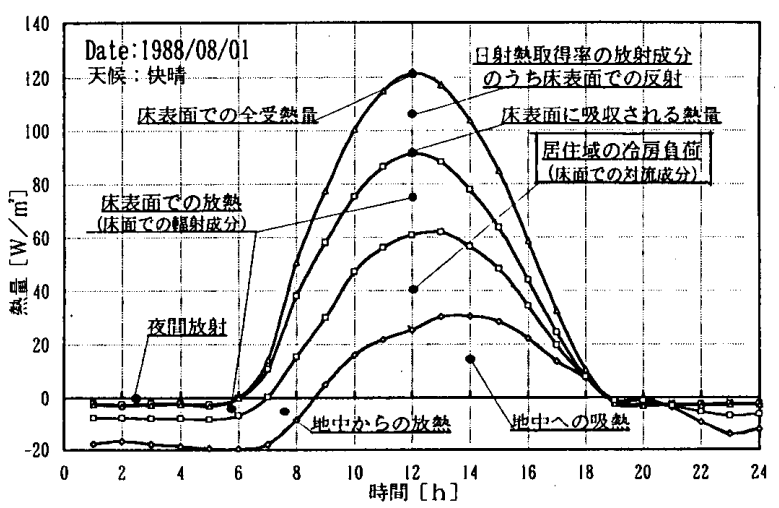

図9 床面での熱負荷の内訳 
1）図10に示したように床と上部膜面、床と上部空気、 床と下部空気、膜と上部空気、膜と下部空気の $5 つ の$ 部 位を考える。図 10 a ）に示す床と上部膜面については、 床面での熱平衡式の中で別途計算するので、ここでは居 住域・非空調域の空気層と膜面、空気層と床面について 取り上げ空気層の輻射吸放熱量について計算する。また、 上部膜面と下部膜面、下部空気層と下部膜面、上部空気 層と下部膜面などがあるが、形態係数が小さいと考え計 算外とした。膜面および床の放射率は 0.85 で一定 とした。室内空気の水蒸気の輻射率 $\varepsilon ，$ は、水蒸気分圧 $\rho$ と空気層の有効厚さ $L a$ の積を $f$ とし、これを独立変 数として求める。飽和湿り空気の水蒸気分圧 $\rho s は \mathrm{We}$ $\mathrm{x} 1$ e r $-\mathrm{Hy} \mathrm{l}$ a n d 式 $^{18)}$ 加、上部空気の絶対 温度の平均値を $T i d^{*}$ とすると、

$$
\begin{aligned}
\ln \operatorname{as}(i)= & -5.8002206 \cdot 10^{9} / \text { Tid }^{*}(i)+1.3914993 \\
& -4.8640239 \cdot 10^{-2} \cdot \text { Tid }^{*}(i) \\
& +4.1764768 \cdot 10^{-5} \cdot \text { Tid }^{*}(i)^{2} \\
& -1.4452093 \cdot 10^{-8} \cdot \text { Tid }^{*}(i)^{3} \\
& +6.5459673 \cdot \ln \operatorname{Tid}^{*}(i)
\end{aligned}
$$

を得る。湿り空気中の水蒸気分圧 $\rho$ 、水蒸気の放射率 と怆

$$
\rho(i)=\phi(i) \cdot \operatorname{as}(i) \cdot 760 / 101325
$$

$\varepsilon_{r}(i)=0.0005 \cdot f(i)^{j}+0.0043 \cdot f(i)+0.0112(25)$

と近似できる。ただし、居住域の空気層の平均温度を Tidとすると、

$$
T i d(i)=\sum_{i=1}^{B} V_{V_{i}} \cdot T i_{i}(i) / \sum_{i=1}^{B} V_{j}
$$

として計算する。また、上部非空調域の平均温度 $T i u 、$ 上部・下部膜面耫、上部・下部膜面温度も同様に求める。 膜面・床面と空気層との輻射による熟流の計算は式 (2 6 ）の代表点の温度を用いて計算する。膜面から空気、 休表面から居住域の空気層に含む水蒸気への吸故熱量 $Q$ $r d$ 隹

$$
Q r d(i)=H r d, \operatorname{lr}(i)+H \operatorname{rd}, \operatorname{ar}(i)
$$

となり、式（2８）から式（32）を用い図１0の（c) (e ）の輻射吸放熱量を求める。

$$
\begin{aligned}
& H n d, \operatorname{lr}(i)=\alpha r, \operatorname{Ir}(i)\{T w(i)-T i d(i)\} \cdot A w d \\
& H r d, a r(i)=\alpha r, 0 r(i)\{T g(i)-T i d(i)\} \cdot A g \\
& \alpha r d, 1 r(i)=C \cdot a b \cdot \varepsilon_{1} \cdot \varepsilon_{\mathrm{r}}(i)\left\{1+\left(1-\varepsilon_{0}\right)\left(1-\varepsilon_{r}(i)\right)\right\} \\
& \alpha \operatorname{rd}, 0 r(i)=C \cdot \omega \cdot \varepsilon_{0} \cdot \varepsilon_{\mathrm{r}}(i)\left\{1+\left(1-\varepsilon_{l}\right)\left(1-\varepsilon_{\mathrm{r}}(i)\right)\right\} \\
& C=\left(\left(T^{*}+1\right) / 100\right)^{4}-\left(T^{*} / 100\right)^{4}
\end{aligned}
$$

ただし、 $T^{*}$ は架気の絶対温度を示し、膜および床の放 射率は 0.85 とした。 $\mathrm{Hrd}, 1 \mathrm{r} 、 \mathrm{Hrd}$, Orの室温に対す る適用範囲は式 (3 2 ) で求める。非空調域の空気への
輻射熱伝達量 QruについてもQrdに準じて計算する。

\section{6 ）加庄送風傤による外気の熱負荷}

加圧送風機から吹き出された噴流は、周囲の空気を誘 引しながら拡散し、噴流の到達層 3 から $5 \mathrm{~m}$ の空間に流 入するものとした。すなわち、図 3 に示す実測結果から、 下部の冷風、上部の温風に挟まれその中間に滞留し下部 の隙間や上部の排気口に流れるものとした。加圧送風機 による新鮮空気の負荷のうち下部居住域への負荷 $Q f d$ は居住域でのエアリークによる排気と外気の比エンタル ピの差とした。上部非空調域での排気口への排気 $Q f u$ は床上 $3 \mathrm{~m}$ と $7.5 \mathrm{~m}$ の実測点の比エンタルピの差とし、 外気と床上 $3 \mathrm{~m}$ の比エンタルピの差は居住域の負荷とし た。 $Q f d 、 Q f u$ の関係式を式（３３）に示す。排気 風量は図 1 の下段および図 4 に示す現地での実測值を用 いた。また、加圧送風機の給気の温度は吸込み口の温度 とし外気温を採用した。

$$
Q f d(i)=\gamma \cdot V d\left\{H_{o}(i)-H d x(i)\right)+\gamma \cdot V u\left(H_{0}(i)-H_{0}(i)\right\}
$$

$$
Q f u(i)=\gamma \cdot V u\left\{H_{4}(i)-H_{3}(i)\right\}
$$

\section{7 ）照明・穖器・加圧送風機の消費電力による熱負荷}

加圧送風機、冷却水ポンプ、パッケージのコンプレッ サの負荷は現地で 1 時間ごとに実測した消費電力量を用 いた。また、照明器具・パッケージの給気ファン、室内 使用機器などは、ドーム専用の分電盤の実測値を用いた。 照明・機器 ·加圧送風機の負荷をQiとすると、

$$
Q i(i)=\sqrt{3} \cdot E \cdot I(i) \cos \phi
$$

となる。照明を含めこれらの負荷は地上部分にあるので 居住域の負荷とした。照明の力率 $\cos \phi$ は 1 ．０、機 器関係は 0 . 85 を採用した。

\section{8) 人体の熱真荷}

人体の発熱量 $Q h$ は居住域の負荷とし、顕熱と潜熱に 分け下式に示す通りとした。

$$
Q h(i)=(54+59) \cdot N h(i)
$$

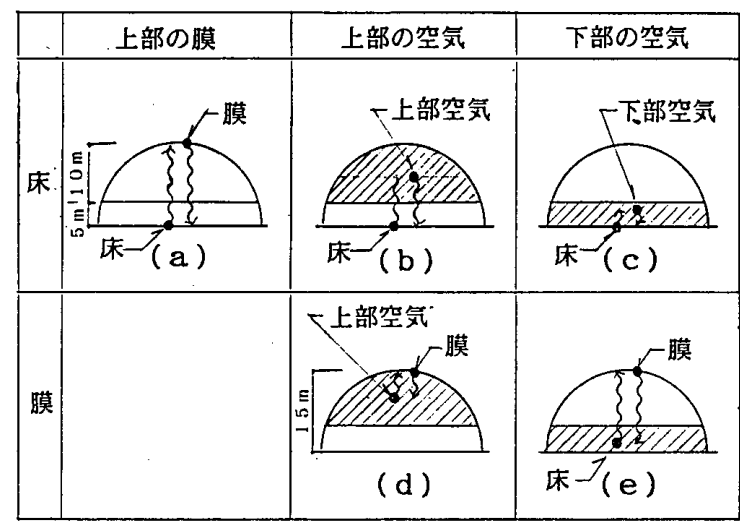

図 10 空気中の水蒸気の輻射吸放熱量の計算モデル 
3.2 居住域の冷房負荷、非空媩域の熱負荷の推定と 考察

园 11 に8月 1 日の居住域の全冷房負荷および式 (2) に示す各部位の熱負荷を示した。居住域の冷房負荷は、 11 時から 14 時頃が大きく、14 時頃に最大 $917 \mathrm{k}$ W程度であった。延べ床面積 $4295 \mathrm{~m}^{2}$ に対して単位 面積当たり $213 \mathrm{~W} / \mathrm{m}^{2}$ で、外気負荷、床、照明・機 器・加圧送風機、膜などの負荷が大きい。特に外気の負 荷が大きい值を示したが、これはパッケージでの除湿に

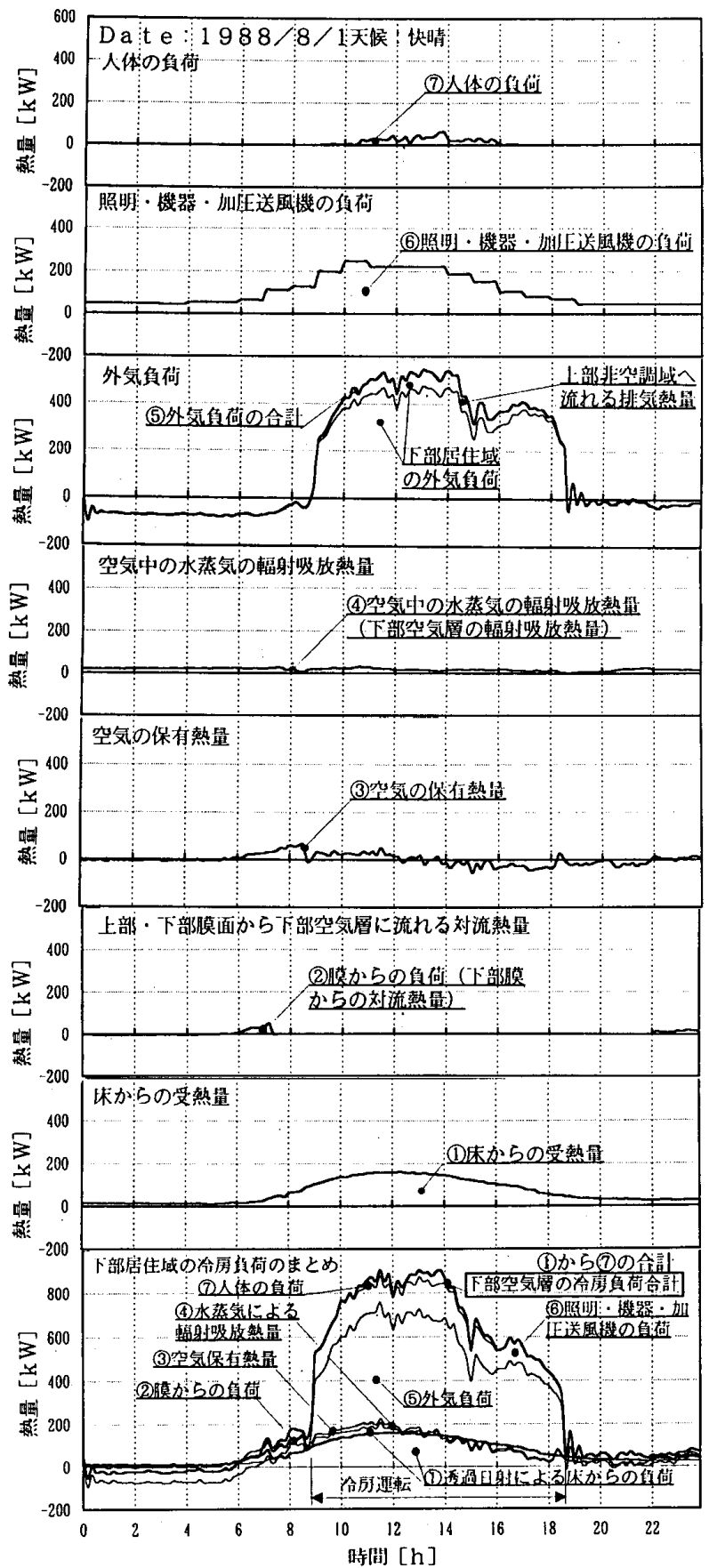

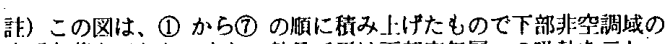
冷房负荷を示した。また、熱最で位は下部空気層への吸熱を示し、 负は下部空気層からの放熱を示す。

図 11 下部居住域の冷房負荷（8／1：快晴）
よるものである。加圧送風機による外気負荷は $537 \mathrm{k}$ Wあり全冷房負荷の $55 \%$ をしめる。このうち実測値か ら求めた計算結果では潜熱負荷が $384 \mathrm{~kW}$ W゙全冷房負 荷の $42 \%$ を示し除湿による潜熱負荷の影響が非常に大 きいことが明らかになった。また、8月 1 日は快晴にも かかわらず、14 時を境に冷房負荷が減少するが、外気 の湿度が低下しパッケージでの除湿負荷が減少したため である。エアドームの冷房に取って、新鲜空気の供給量 や漏気量を減らし外気負荷を軽減する対策が必要といえ る。また、図 12 は、式（3）に示す上部非空調域の熱 負荷を示した。前述したようにこの負荷は直接パッケー ジの負荷にはならない。前報 ${ }^{2}$ および図2 に示した通り、 自然室温と冷房時の垂直各点の温度の間には 5 から 10 ${ }^{\circ} \mathrm{C}$ 程度の温度差が生じ、実測值から求めた計算結果では、 居住域の冷房負荷の $10 \%$ 程度になり、冷房負荷は頂部 までおよふことが明らかになった。

\section{4 冷却塔の除去热量と居住域の冷房負荷の比較}

表 1 に冷却水配管系の実測条件を示した。図 13 の位 置で冷却塔の出入口温度、冷却水量を実測した。また、

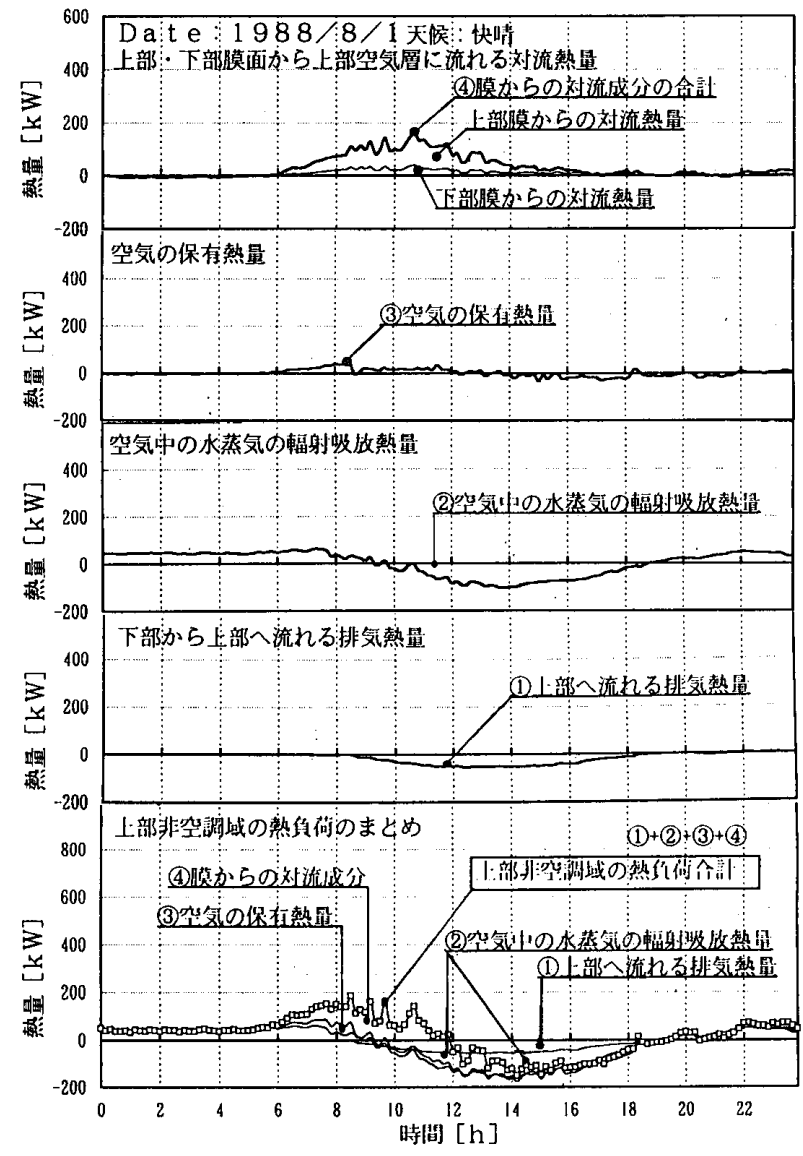

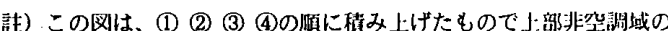
吸放熱量の合計は(4)となる。また、熱量で证は上:部空気原への吸熱 を示し、負は上部空気層からの放熱を示す。

図 12 上部非空調域の熱負荷（8/1：快晴） 
地中配管での除去熱量も計算対象とした。

\section{1 冷却塔の除去熱量の算定方法}

冷却水の除去熱量の実測值を用いて冷房負荷 $Q c t$ を 求める。冷却水の水量を $L$ 、冷却塔の出入口温度を $T r$ 、

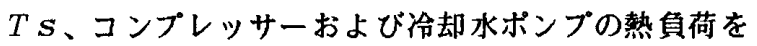
$Q c m 、 Q c p$ 、冷却水配管の熱損失を $Q p$ とすると下 記の熱平衡が成り立つ。

$Q c t(i)=L\{\operatorname{Tr}(i)-\operatorname{Ts}(i)\}+Q p(i)-\{Q c m(i)+Q c p(i)\}$

Lは超音波式流量計を用いて計測した実測值を用いた。 また、実測の結果出入口の温度差はそれほど大きくは無 い。また、往き還りの温度に乱れは無く正確に測定され ているので、冷却水側で常時実測している装置負荷の推 定精度は高いと考えられる。配管の熱損失 $Q p$ は、各配 管口徍について、下式（37）功式（40）を用いた。

$$
\begin{aligned}
& Q p(i)=K p\{T p(i)-T g i(i)\} s_{1} \\
& s_{1}=\pi d_{1} \cdot 1 \\
& s_{2}=\pi d_{2} \cdot 1 \\
& K p=1 /\left\{1 /\left(\alpha_{1}+2.303 \cdot d_{1}\right) / 2 \lambda \cdot \log v_{0}\left(d_{1} / d_{2}\right)\right. \\
& \left.\quad+1 / \alpha_{2} \cdot d_{1} / d_{2}\right\}
\end{aligned}
$$

ここに、Kpは配管内怪と外径との間の熱貫流率を示し、

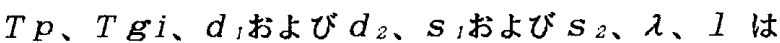
それぞれ管内表面温度、地中温度、配管の内径および外 徍、内表面積および外表面積、塩ビ管の熱伝導率、各口 径の配管長を示す。つぎに、 $K p$ を求める場合に、水側

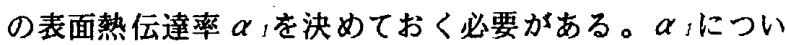
ては、Dit t us、Boet 1 e $r^{19 !}$ による実験式 から求めるが、 R eが 10000 以上の場合は、

$$
\alpha_{1}=\lambda / d_{1} \cdot 0.023\left(V \cdot d_{l} / \nu\right)^{a}(C p \cdot \mu / \lambda)^{0.4}
$$

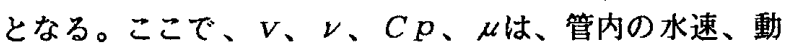
粘性係数、水の比熱、絶対単位の粘性係数で重力単位の 粘性係数と重力の加速度との積を示す。また、Qpは配 管のほとんどは地中配管であるので、実測を行った配管 の流量、往き還りの温度を与え、式 (37) を用い収束 計算を行って求めることができる。つぎに、Qcm、Q $c p$ は、パッケージの運転時間中 1 時間ごとに手計測で 7 系統の専用分電盤の電圧および電流值を実測し、各パ ッケージの送風機動力を差し引いたものをコンプレッサ 一の消費電力とした。ポンプの消費電力は、同様に電圧 と電流値を計測し求めた。熱負荷への換算は、式 ( 34 ) を用いた。コンプレッサおよびポンプのカ率はいずれも 0.85を採用した。

\section{2 冾却塔の除去熱量と熱負荷の推定值を比較}

式（2）を用い8月 1 日の室内の冷房負荷を計算し、 この值にパッケージのコンプレッサ、冷却水ポンプの消
費動力による負荷を加算したものが冷却塔および地中配 管で除去される熱量となる。図 14 のプラス側の(3)=(4) +(5)-(1)- (2)が負荷側の全冷房負荷を示し、プラスまた はマイナス側の(4)+(5)は冷却塔および地中配管での除去 側の熱量を示した。ただ、地中配管の除去熱量(5)は実 測値をもとに冷却水の出入口温度差が合うまで収束計算 を行い求めた。計算の結果、冷房負荷計算により求めた 負荷側と冷却塔での除去側の熱量に相違はあまりなく、 実測值と計算值には整合性があるといえる。また、地中 配管の除去熱量は、全除去熱量の 20 から $25 \%$ 程度で あり、地中配管の冷却効果はある程度大きいといえる。

\begin{tabular}{|c|c|}
\hline 項 & 項 \\
\hline 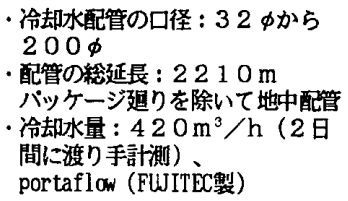 & 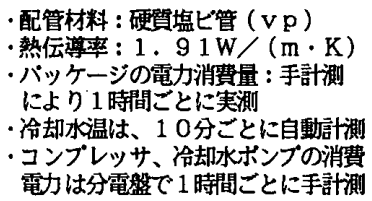 \\
\hline
\end{tabular}

5 エアドーム内の上下温度差で単位面積当たりの

\section{熱負荷を推定}

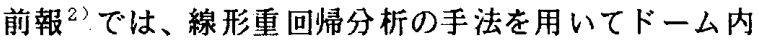
の床上 $0.1 \mathrm{~m}$ と床上 $14.4 \mathrm{~m}$ 垂直温度分布を推定

表 1 冷却塔の除去熱量実測条件

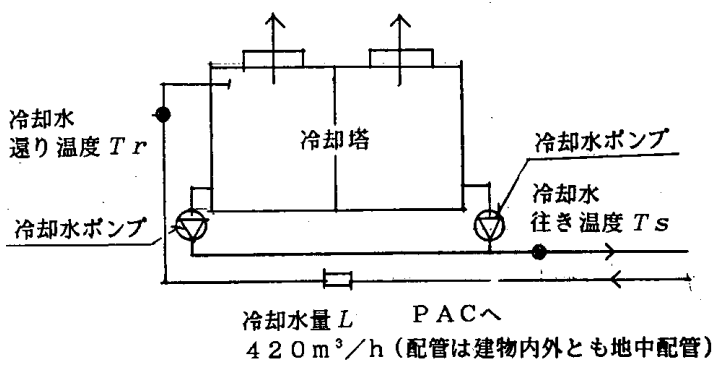

図13 冾却塔周りの実測点

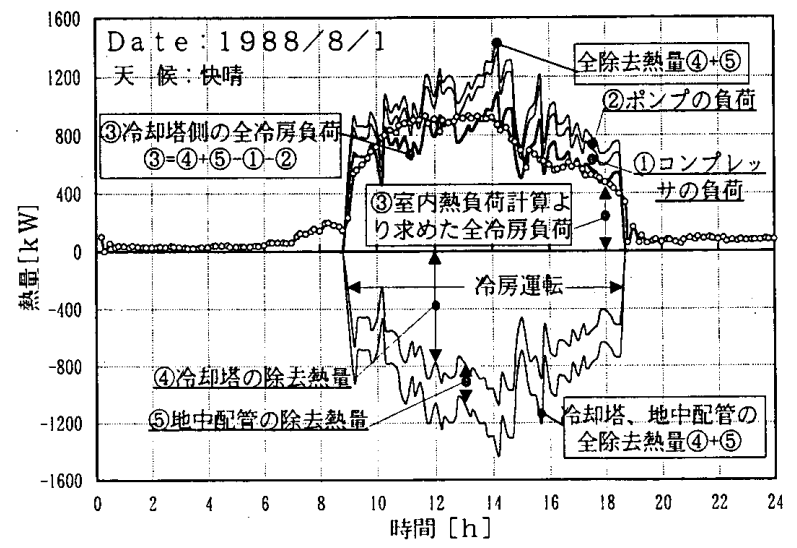

図 14 室内全泠房負荷と冷却塔の除去熱量の比較 
した。ここでは、この 2 点間の温度差と全冷房負荷の関 係について明らかにする。 8 月 1 日の9時から 18 時 3 0分の間冷房運転を行った。実測は 10 分間ごとの值に ついて求め図 15 に示した。上下の温度差 $X$ と全冷房負 荷 $Y$ の間には、

$$
Y=47.949 X+192.49
$$

関係がある。重相関係数は０８993で上下温度差と パッケージの冷房負荷の相関性はある程度高いといえる。

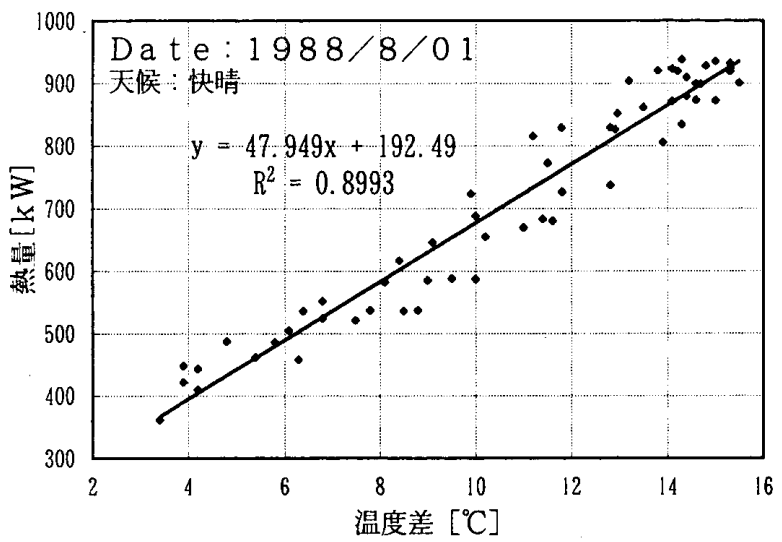

図 15 床面と頂部の温度差と冷房負荷

（床面 $0.1 \mathrm{~m}$ 、頂部 $14.4 \mathrm{~m}$ )

\section{6 結論}

線形重回㷌分析の手法を用い、エアドームの夏期冷房 負荷の推定を行った。また、この計算結果と冷却塔の除 去熱量の実測值を比較し以下のことが明らかになった。 1) 夏期冷房時の熱負荷に対する膜材の内表面伝達率の 対流成分は $5.7 \mathrm{~kW} / \mathrm{m}^{2} \cdot \mathrm{K}$ 、床面は 6 加ら 7.2 $\mathrm{kW} / \mathrm{m}^{2} \cdot \mathrm{K}$ 程度となる。

2 ）加圧送風機を用いたエアドームでは、外気負荷が冷 房負荷にしめる割合は大きい。特に、パッケージで除湿 されるので、室内空気と外気の絶対湿度の差が冷房負荷 に影響する。

3 ) 晴天日で夏期冷房時の熱負荷は最大 $213 \mathrm{~W} / \mathrm{m}^{2}$ 前後となった。日射熱取得率の放射成分の影響を受け床 面が加熱されるので床面の熱負荷は比較的大きい。また、 膜面と空気、床面と空気の間に輻射伝熱があり、それほ ど多くはないが空気層にも長波長放射による吸放熱量が ある。

4) 自然室温と冷房時の垂直温度分右には温度差がある が、地上 5 メートル以上の非空調域にも冷房負荷の 10 $\%$ 程度の熱負荷が存在する。

5 ）冷房時の熱負荷の推定值はほぼ冷却塔の除去熱量お よび地中配管から地中への熱損失の和に近い值を示した。 また、地中配管の除去熱量は全除去熱量の2 5 加 33 \%で比較的大きい割合を示した。

6 ）室内床部と頂部の温度差と、居住域の冷房負荷の相
関を調べた結果、温度差 $1{ }^{\circ} \mathrm{Cにつき} 3.8 \mathrm{~kW} / \mathrm{m}^{2}$ 程 度の熱負荷となる。

7 ）気象データとして得られる水平面全天日射量、外気 の温度・湿度、外風速の 4 つを独立変数とし、照明、人 体などの内部負荷が判れば、線形重回帰分析の手法を用 いて冷房負荷を推定することが可能である。

以上の結果より、重回帰分析の手法を用いた統計的な 熱負荷の推定は有用であるといえる。

\section{㖊辞}

本論文の作成に当たって、資料の収集、実測にご協力 いただきました奈良県土木部建築課、菊竹建築設計事務 所の方々をはじめ関係各位に心より深謝いたします。

\section{参考文献}

1）传野武仁：膜情造建築に用いる㙁ビ膜とフッ素樹脂膜の光特性 と熱特性に関する実駼研究，日本建築学会計画詰論文集第45 1 号, p p 19-27, 1993年9月

2) 佐野武仁：大空間土アドームの夏期, 中間期における垂直温度

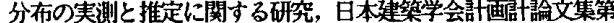
472 号, P P 21-29，1995年6月

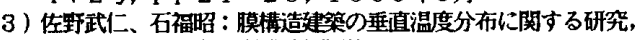
日本建筑学会大会学術講演梗脚集, P P 1 4 73-1474, (関東) 1993 年9月

4 ) 传野武仁、石福昭 : 膜構造建築の垂直温度分布に関する解析, 空気調和・衛生工学会学術講寅会論文集, P P 7 7-80, 993.10

5 ）传野武仁、石福昭：重回埽分析による膜棈造物の垂直温度分布 に関する研究，日本建築学会大会学術講演梗概集，D環境工学 p p 543-544,1994.9

6) 伎野武仁、井上宇市、石福昭、田辺新一、島田雅世：膜構造屋 内フールの謤境実測㧍よび解析（その2）（温水ブールの室内

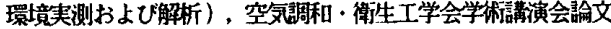
集, P P 541-544，1992.10

7 ) 传野武仁、石福昭、栗岡久美子：大空間膜構造建築・SALT IMBANCOO温熱擐境関する研究，日本建策学会大会学 術講演梗概集, 環境工学D - 2, p p 95-96, 1995 .

8 ）传野武仁、桑田意子：大空間膜槽造建築の垂直温度分布に関与 る模型実験およひ解析, 日本建築学会大会学術講演梗概集, 㻴 境工学D -2 , p p $91-92,1995.8$

9 ) 佐野武仁、黄辰、石福昭：大空間エアドームの熱負荷の推定に 関する研究 (要期), 日本建筑学会大会学術譜演梗概集, D 2濖境工学 II p p 93-94,1995.8

10 ) 宮川保之: 大空間の熱的環境の予测と調整に関する研究，学位 諭文 (早槄田大学)，昭和58年7月

11 ) 戸河里敏、早川面、荒井良延: 大究間・アトリウムの熱環境部 画手法の研究（その1）上下温度分布の简易预测モデル, 空気 調和·得牲工学会学術講演会会文文集, p p $541-544,1$ 988.9

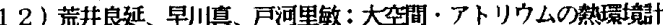
画手法の研究（その2）アトリウムの透過日射熱取得の計算法,

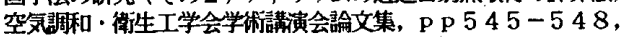
1988.9

13 ）早川蒖、声河里敏、荒井良延、三浦克弘：大究間・アトリウム の熱環境部画手法の研究 (その3) 全面的にトッブライトを有 するアトリウムの熱噮境の実則・解析, 空気調和・得生工学会 学術請演会論文集, P P 5 49-552, 1988 .9

14 ) 木村建一：室内表面と室内空気との間の辐射熱伝達, 建築設徣 基硞理諭演習，学献社，P p 293-295，1987. 3

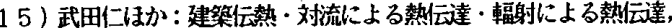

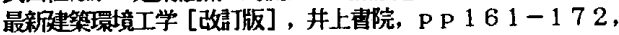
井上書院, 1993.12

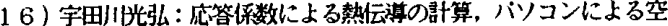

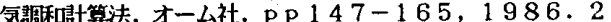

17 ) WILLIAM.H.MCADAMS : HEAT TRANSMISSION, MEGRAW-HILL BOOK COPPANY INC., P p 82-94,1958

18 ) 日本機械掌会: 湿り空氞の熱物性檤, 伝熱工学資料, 丸善, P P, $355,1989.7$

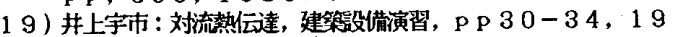
64. 10

(1995年10月11日原稿受理, 1996年 6 月 20 日採用決定) 